\title{
On the Socratic Injunction to Follow the Argument Where It Leads
}

\author{
Jason Marsh
}

"The lover of inquiry must follow his beloved wherever it may lead him."

Socrates

\subsection{Introduction}

All of us risk coming across unanswerable objections ${ }^{1}$ to our beliefs. How should we respond to such objections if they arise? According to one tradition, we should be open to revising our beliefs. On this view, Socrates' willingness to let inquiry drive him almost anywhere remains an ideal for philosophy and science. Indeed, defenders of this view often claim that the chief aim of philosophy is to question our opinions and to take seriously the Socratic injunction to follow the argument where it leads. ${ }^{2}$

By contrast, another tradition is far less concessive, at least when it comes to philosophical objections to common sense. On this view, most often associated with G. E. Moore, ${ }^{3}$ unanswerable challenges to what we

\footnotetext{
${ }^{1}$ By "unanswerable objection" I mean an objection that an agent cannot answer even after sustained reflection. Such an objection needn't be intrinsically unanswerable.

${ }^{2}$ I am told that the idea of "following the argument" ultimately originates with Parmenides.

${ }^{3}$ Some also associate this view with Thomas Reid.
} 
ordinarily believe often have less epistemic weight than our beliefs themselves. For instance, if an undergraduate finds Zeno's argument against the reality of motion irrefutable, she is not likely to abandon her belief in motion. She will instead conclude that there must be something wrong with the skeptical challenge, even if a problem cannot be identified. Or she will at least conclude that the skeptical argument in fact fails, even if a problem cannot be identified. ${ }^{4}$

I cannot hope to settle the general dispute between Socratics and Mooreans here. Instead, my focus will be more specific: even if we think we can sometimes reasonably deflect challenges, in the way that the Mooreans suggest, how far might this be extended? If someone were to insist that his or her religious beliefs, for instance, had enough intrinsic weight to simply set aside the problem of evil, should this be deemed reasonable?

Although many will think that the answer is clearly "no," some philosophers of religion are starting to claim otherwise. For such philosophers, one can reasonably think of religious beliefs as having a kind of Moorean status, rendering them more obvious than at least any of the known arguments against them. One consequence of this view is that even the best argumentative challenges to various religious ideas, whether they have been refuted or not, need not be followed.

My task in this chapter will be to argue that there are reasons against promoting religious Mooreanism in the field, reasons that are available even to traditional Mooreans. To clarify, I will not be arguing that religious Mooreanism is definitely false, only that the view is in tension with the Socratic injunction, that it is less plausible than more familiar forms of Mooreanism, and that it, in any case, has yet to be adequately defended. In light of these points, my advice for philosophy of religion is that the Moorean methodologies I explore here should be considered out of bounds in the field unless and until such methodologies are better motivated. This advice, to clarify, need not apply only to religious philosophers, but also to any secular critics of religion who are tempted to attribute Moorean status to their secular ideas.

\footnotetext{
4 There are naturally different ways to understand both Mooreanism and the Socratic injunction. For a helpful overview of these ways, see Kelly 2005 and 2011.
} 


\subsection{Preliminary Remarks}

There are different ways that a field might fail to sufficiently promote the Socratic injunction. For some, the crucial example in a field like philosophy of religion will be ideas that restrict the search for further evidence concerning the divine. For instance, on Lara Buchak's analysis of faith, theistic faith requires willingness to refrain from gathering further evidence in order to determine the truth about God's existence (2012). ${ }^{5}$ In addition, Huw Price is a secular critic of religion who claims that we should stop even engaging arguments for the divine (2007). ${ }^{6}$

I will not be focusing on examples of restricting the search for new evidence, but on deflecting known evidence-and in particular known counter-evidence to religious belief that is widely thought to be powerful, such as the best evidential arguments from evil. Whether or not this known evidence would actually undermine the target religious beliefs is not something I need to take a stand on here. It would be sufficient, for my purposes, that the objections would have the potential to generate full or partial defeat in many instances.

Another caveat worth mentioning concerns how to raise Socratic worries about philosophy of religion. Unlike some philosophers, I will not claim that any particular individuals are not Socratic. My approach thus stands in contrast to Bertrand Russell's when he says the following in his History of Western Philosophy:

There is little of the true philosophic spirit in Aquinas. He does not, like the Platonic Socrates, set out to follow wherever the argument may lead. He is not engaged in an inquiry... Before he begins to philosophize, he already knows the truth; it is declared in the Catholic faith. If he can find apparently rational arguments for some parts of the faith, so much the better: If he cannot, he need only fall back on revelation. (Cited in Kelly 2011: 105)

5 To be fair, Buchak states that how rational faith is depends on whether the search for further evidence would be decisive. She also explores the decision-theoretic benefits of faith.

${ }^{6}$ This explains Price's refusal to even engage John Leslie's arguments while reviewing one of his books. In Price's words, "While it seemed possible, even tempting, to engage with Leslie on particular philosophical points, taking theology at face value would have seemed a kind of moral defeat: feeding an ancient intellectual cuckoo that would be better simply starved" (2007). Price has reasons for his stance. But to many his stance will appear deeply premature (Schellenberg 2007) and, one might add, deeply un-Socratic. 
Whether or not Russell is being fair to Aquinas, my point is just that I am not aiming to be personal in the way that Russell is: my emphasis will be on ideas, not people. It may be that all the individuals I consider are fully Socratic, even if some of the ideas they promote are not. In fact, it may be that most ideas in the field are Socratic. I am just focusing on one trend.

Finally, although I shall be contrasting Socratic and Moorean approaches to philosophy, I am fully aware that one could overstate their differences. After all, not even Socrates thought that the law of non-contradiction was open to question. ${ }^{7}$ What's more, if "following the argument where it leads" can be understood to mean "following the evidence where it leads," as I think it can, ${ }^{8}$ then Mooreans may well think that they do follow the evidence. They just think that Moorean evidence has more strength than the known counter-evidence.

Despite these remarks, though, there remains a clear difference between the two traditions in question. Socrates seems more willing to be challenged more of the time, more willing to claim ignorance as opposed to knowledge, and more open to discovering new evidence that his prior evidence was misguided. It is this degree of openness to epistemic risk and human fallibility, which many see as epistemic virtues, ${ }^{9}$ that explains the core difference between Socrates and Moore.

\subsection{Three Varieties of Religious Mooreanism}

To better understand how Mooreanism operates in the philosophy of religion it is helpful to start with the work of Alvin Plantinga. I start with Plantinga not because he goes as far as the traditional Moorean. Unlike secular Mooreans who claim that the traditional skeptic literally could not win, Plantinga never says that the religious skeptic could not win, ${ }^{10}$ nor does he refuse to engage the religious skeptic. Rather, I start with Plantinga because, as at least one other person has appreciated

\footnotetext{
${ }^{7}$ Kelly makes this point. But it should be noted that some philosophers think that even logic and math can be overturned.

${ }^{8}$ As many epistemologists have noted, evidence can include testimony and perception, and these things aren't best thought of as arguments.

9 Instead of interpreting "following the argument" as an epistemic duty, I prefer to think of it in virtue-theoretic terms: it is generally an epistemic virtue to give arguments their due, and a vice not to.

10 Though he thinks irreligious experiences are much more likely to defeat theistic belief than irreligious arguments.
} 
(Leon 2010), his views paved the way for thinking about religion in way that has clear Moorean features.

After all, Plantinga did not merely introduce the idea that belief in God could be justified, rational, and, if true, an item of knowledge in the absence of arguments. He further introduced the idea that skeptical challenges to belief in God could be deflected in the absence of arguments. He did this when he introduced the notion of intrinsic defeaterdefeaters into the field. Plantinga defines an intrinsic defeater-defeater as follows: "When a basic belief $p$ has more by way of warrant than a potential defeater $\mathrm{q}$ of $\mathrm{p}$, then $\mathrm{p}$ is an intrinsic defeater of $\mathrm{q}$-an intrinsic defeater-defeater, we might say" (1986: 311).

A common example employed by Plantinga runs as follows. Suppose that all of the available public evidence (e.g., eye-witness testimony, DNA evidence, etc.) supports the claim that you committed a horrible murder this morning. You might come to grant that this public evidence condemns you. But suppose you also have a clear memory of hiking in the woods all morning and have no memory of ever contemplating a murder. According to Plantinga, given your clear memory beliefs, you might continue to rationally affirm your innocence. That is to say, your noninferentially justified private evidence could function as an intrinsic defeater-defeater of the public evidence that, by your own lights, stands against you in third-personal terms.

Trusting that others will agree with his example, Plantinga raised the possibility that something similar could happen in religious contexts. Maybe someone's private and non-inferential religious evidence (e.g., from religious experience) might be sufficient in strength to simply overwhelm the public inferential objections, whether or not she can answer them.

In response to the charge that such claims would permit various seemingly unanswerable challenges to religious belief to have little bite, Plantinga's view seems to be that this isn't a problem. For he claims that our non-religious basic beliefs are often improbable on the public evidence and that this often doesn't count against them in the least. (More on his parity arguments in due course.)

\subsubsection{Standard religious Mooreanism}

According to our first variety of religious Mooreanism, then, core religious beliefs-for Plantinga this includes theistic belief and some Christian 
creedal beliefs ${ }^{11}$ - typically have more intrinsic weight than the best objections to those beliefs. Let us call this idea standard religious Mooreanism.

To be a bit more precise, one counts as a standard religious Moorean, on my definition, if one endorses the idea that most believers in most instances would be epistemically well positioned to deflect even the most sophisticated and enduring known challenges to their religious beliefs (e.g., the problem of infant suffering or the problem of divine hiddenness), whether or not they, or someone they know of in their community, could satisfactorily answer those objections.

So far as I can tell, Plantinga is committed to standard religious Mooreanism. For although he personally thinks the objections to theism can and should be answered by theistic philosophers (2001: 217), the question is what such philosophers are to do if they fail, by their own lights, to come across convincing answers to the challenges. Plantinga implies that philosophers, sophisticated adults, and uneducated believers in such circumstances can typically fall back on their noninferential evidence to defeat the challenger. Indeed, if theism is true, says Plantinga, then the very fact that someone continues to affirm belief in God in the face of objections is evidence that her divine sense is functioning properly and that she is externally rational (2000: 492). But even if theism is false, deflection will often be internally rational on his view, since it involves an agent sticking to what seems true to her (2000: 492).

Another standard religious Moorean is, interestingly, a non-theist. In particular, William Rowe, in his oft-cited paper "The Problem of Evil and Some Varieties of Atheism" recommends a Moorean response to the problem of evil. After presenting his own argument from evil, which he himself finds persuasive, Rowe offers the theistic philosopher a quick way out. He states:

The best procedure for the theist to follow in rejecting [a key premise in my argument] is the indirect procedure. This procedure I shall call "the G. E. Moore shift," so-called in honor of the twentieth-century philosopher, G. E. Moore, who used it to great effect in dealing with the arguments of the skeptics... [H]aving rational grounds for rejecting [a key premise in my argument], the theist concludes that the basic argument for atheism is mistaken. (1979: 359-60)

11 Followers of different traditions might naturally wish to revise the list. 
Although Moorean deflection can take a purely non-inferential form, as we saw in Plantinga, the Mooreanism recommended by Rowe is a little more inferential but still extremely quick and easy. It basically comes down to the following argument. (1) If the skeptical challenge were successful, then my belief would be false. (2) My belief is true. (3) Therefore the skeptical challenge fails.

The question facing Rowe's Mooreanism, to be clear, is not whether it would be dialectically effective in a philosophical exchange with a nonMoorean. No doubt it would not be and the Moorean can admit this. The question facing Rowe is rather whether the proposed Moorean shift is epistemically defective for those who make use of it. Rowe does not seem to be too worried about this question. For he simply advises, without argument, that the theist-and one might add, the theistic philosophernot follow his own argument from evil. Since there is no clear reason why Rowe wouldn't permit a similar move in response to other arguments, such as hiddenness arguments, it is very tempting to characterize him as a standard religious Moorean.

This interpretation also sits well with Rowe's "friendly atheism," according to which his theistic colleagues are rational even if he thinks they are objectively mistaken. While Rowe's intentions seem laudable to me, one might wonder whether promoting Mooreanism is the best way to be friendly. For one might have thought that an even better piece of advice for theistic philosophers would be to do something many of them already seek to do: namely to engage Rowe's argument head on, pointing to some mistaken premise, assumption, or piece of reasoning.

A third example of a standard religious Moorean is arguably Michael Bergmann. Bergmann characterizes religious Mooreanism in terms of theistic seemings (Bergmann 2014). On this view, theistic seemings (and the higher-order seemings that the theistic seemings are veridical, which arise when we reflect on the theistic seemings) are very often strong enough to defeat the prospective defeaters to theism. Bergmann's suggestion, to be clear, is not that theistic seemings are as strong as our seeming that there is an external world. His suggestion is rather that the relevant seemings might nonetheless often be strong enough to deflect theistic skepticism. A consequence of this claim about "felt veridicality" is this: in response to even the tougher skeptical challenges to theism, the believer has a non-inferential escape route. 
To be sure, Bergmann personally addresses counter-arguments in more inferential ways. Like Plantinga, he offers detailed arguments in response to Rowe's arguments from evil, for instance. But even if Bergmann seeks to follow the argument, the question is whether his Mooreanism permits others to be much less reflective by allowing them to non-inferentially deflect even the best objections to theism (e.g., divine hiddenness, infant suffering, and religious diversity), without suffering full-or in many cases, even partial-defeat.

\subsubsection{Strong religious Mooreanism}

The standard religious Mooreans we have been describing think that core religious beliefs are largely but not entirely resistant to defeat. But there are stronger views on offer. According to strong religious Mooreanism, core religious beliefs such as theism are indefeasible in the following sense: provided the target beliefs are true and properly formed, and provided that a believer is sufficiently firm and attentive, nothing need shake her beliefs. While almost no one in the field endorses strong religious Mooreanism, one apparent exception is William Lane Craig. He states:

So I do not think, nor have I ever claimed, that we should always "move towards where the evidences lead us." Evidences are shifting and in a given circumstance may not point toward the truth... What's at issue here... is whether holding that the witness of God's Spirit is indefeasible leads to some epistemic misstep. If it does, then I'll gladly give up that claim. After all, that claim is not essential to Reformed Epistemology, much less Christianity. But I don't see that you've identified any epistemic transgression so far. (Craig 2014a)

This passage comes from a brief question and answer forum, but Craig says similar things in his published work. ${ }^{12}$ On his outlook, certain religious beliefs are not merely innocent until proven guilty; they apparently can resist any prospect of becoming guilty given the right conditions. Craig is thus going beyond Plantinga's religious epistemology. Whereas Plantinga's framework makes reasonable religious belief "easy to get and hard to lose," ${ }^{\prime 13}$ Craig seems to want it to be easy to get and, at

\footnotetext{
12 He states: "[A]rguments and evidence incompatible with that truth [of Christianity] are overwhelmed by the experience of the Holy Spirit for him who attends fully to it" (Craig 2008: 15).

${ }^{13}$ I owe this phrase to Jon Marsh.
} 
least for the sufficiently steadfast believer, impossible to lose, in an epistemic sense.

This Moorean attitude also explains Craig's reaction to Paul Draper's advice that religious and secular philosophers of religion should spend more time testing their beliefs and less time trying to protect those beliefs. In response to this Socratic advice, Craig offers the following counter-advice to believers: "[Y] ou do not need to be willing to engage in the risk of [becoming an unbeliever] in order to carry out responsible, philosophical inquiry within such a paradigm" (Craig 2014b).

To be sure, like Plantinga, Rowe, and Bergmann, Craig personally cares a lot about arguments. His concern with arguments is not equivalent to promoting open-mindedness about his first-order religious beliefs, however. For although Craig will permit that his case from natural theology might need to be revised or even abandoned, there would still remain a second non-inferential source of warrant and rationality that is far more secure anyhow, on his view. This second source of warrant and rationality is said to be sufficient in strength to overwhelm any objections to core Christian claims.

But what, then, are we to make of Craig's claims about defeat? He states, for instance, that if the resurrection didn't occur, then his specific religious outlook would not in fact be safe from defeat, at least when it comes to knowledge - for then his outlook wouldn't even be true. Such a concession does not render Craig's view less than Moorean, however. For the traditional Moorean can say, "if I don't have hands, then my belief that I have hands is not objectively safe from defeat." The question is not whether one can make such conditional claims. The question is whether one's current philosophy of defeat, combined with one's actual beliefs, promotes the idea that people can avoid having to test their beliefs and can avoid having to answer difficult objections they stumble across (whether or not they in fact do).

Put another away, even if Craig's Mooreanism about religious knowledge depends on whether God in fact exists, his advice functions to promote a Moorean attitude, whether or not God exists.

\subsubsection{Weak religious Mooreanism}

This is not to say that all versions of religious Mooreanism are nearly so strong. According to a third and final version of religious Mooreanism, certain rare individuals with uniquely powerful religious 
experiences—-for example, Buddha, St Catherine of Siena, or St Paul—are in a good position to deflect any of the known objections to their core religious beliefs. In addition, defenders of this view might add that the common believer can simply deflect objections to her views in cases where the objections are either flimsy, poorly formulated, or not adequately grasped. Call the combination of these ideas weak religious Mooreanism.

From what I can tell, weak religious Mooreanism is not especially troubling. For I am happy to grant that experience and testimony have some epistemic weight—and that this weight is sufficient, in some cases, to overcome an objection all by itself. In fact, I can imagine that if I had the kind of religious experience reported by certain rare individuals, such as Joseph Smith, that deflection would come very naturally. ${ }^{14}$ I will thus say nothing more about weak religious Mooreanism. My concern is with the standard and strong varieties.

\subsection{Why Religious Mooreanism Is Not Socratic}

We have seen that religious Mooreanism, even if a minority view, is a real phenomenon in the philosophy of religion. I now want to raise two challenges for promoting religious Mooreanism in the field.

My first challenge concerns the Socratic injunction. The standard and strong forms of Mooreanism that we have been describing appear to violate Socrates' injunction, if not in letter then in spirit. For as mentioned earlier, Socrates' methodology is not just about arguments. It is about open-mindedness to being challenged, at least in domains that are properly subject to critical investigation. If philosophers were to recommend Mooreanism in other domains, such as politics, we would likely see their methodology as more dogmatic than Socratic. So why invite a Moorean methodology in the context of religion?

Some Mooreans might acknowledge the tension but insist that the Socratic injunction is the real culprit and ought to be given up. ${ }^{15} \mathrm{I}$ do not recommend this path, however. For although it is not my aim to

\footnotetext{
14 Unless, that is, an unusually plausible debunking challenge were formulated.

15 Some might attempt to show that the view has wider skeptical implications, for instance.
} 
defend the Socratic injunction here, ${ }^{16}$ one attractive feature of Socrates' approach should be clear: without something like it, there could be no obvious basis for criticizing being a Moorean about practically anything, including one's Mooreanism. For this reason, a better response, it seems to me, would be for the religious Moorean to simply acknowledge her conflicting methodological commitments to Athens and Jerusalem. Or even better, the religious Moorean might seek to deny that the conflict between Socrates and Moore is even legitimate.

The best way to defend the latter idea was alluded to earlier and comes in two steps. Step one involves interpreting the Socratic injunction as following the evidence, broadly construed, where it leads. ${ }^{17}$ Step two involves defending the priority of non-inferential evidence thesis, according to which non-inferential evidence is such that, even in highly controversial contexts like religion, it almost always trumps even the most difficult-to-answer philosophical objections. If these two steps were successfully taken, then following the evidence would often require deflecting in religious contexts-eliminating the tension between Socrates and religious Mooreanism.

In response, I think the basic tension remains intact. For Mooreanism still arguably makes inquiry much safer, and belief preservation much easier, than Socrates would advise. Plantinga, to his credit, appreciates a version of this worry, as do some of his religious critics (McGrew 2010). ${ }^{18}$ In a section of his book on science and religion called "Can Religious Belief be Defeated?" he states:

But isn't this [i.e., the idea that experience-based basic beliefs trump counterarguments] just a recipe for intellectual irresponsibility, for hanging on to beliefs in the teeth of the evidence? Can't a Christian always say something like the above, no matter what the proposed defeater? (2011: 183)

Plantinga responds by insisting that defeat is possible. He offers the example of modern science defeating geocentric readings of scripture.

\footnotetext{
${ }^{16}$ I am assuming merely that the Socratic injunction, given its sheer influence, makes a claim on ideas in Western philosophy.

${ }^{17} \mathrm{I}$ am told that Michael Bergmann interprets the Socratic injunction this way.

18 As Lydia McGrew appreciates, the objection here isn't inherently secular. She notes, "I was a Christian before I was a philosopher. But there came a time when I questioned that. And I think when that comes, and I think that's going to come for anybody, you ought to have evidence. And I don't think that falling back on something like, this is properly basic, as in, that's Plantinga's system. I don't think that's correct" (McGrew 2010).
} 
I appreciate this response, which implies that there can be a tension between Socratic and Moorean approaches on his view. Still, one wonders if Plantinga is tackling an easier Socratic objection where harder Socratic objections are clearly more pertinent. For even if Plantinga does not make defeat impossible, the harder objection is that his approach nonetheless makes resisting defeat too easy, particularly in the case of core religious beliefs. A related worry is that his approach makes inquiry into religious matters too risk-free. His geocentricism example leaves these objections untouched.

\subsection{Why Religious Mooreanism Is Premature}

Suppose, however, that the tension between Socrates and religious Mooreanism could be eliminated. Even then there would remain a second obstacle to promoting (and one might add endorsing) religious Mooreanism in its strong or standard forms. For religious Mooreanism has not, to my knowledge, been adequately argued for. This is a problem since, as a philosophical thesis, religious Mooreanism is the kind of thing that is supposed to be argued for. It is also the kind of thing that is supposed to be defended from objections, as some Mooreans admit. ${ }^{19}$

If that is right, then in the absence of good and undefeated reasons for claiming that some belief $\mathrm{p}$ has Moorean status, philosophers should not promote the idea that $\mathrm{p}$ has Moorean status in their philosophical work or while operating as philosophers. But then a problem arises. After all, what are the reasons offered in support of religious Mooreanism? When it comes to Rowe, recall, he offers no arguments for his Moorean stance. He just sort of announces that stance. As for Bergmann, his main work in the area has yet to be completed, so we will have to wait and see.

Craig, by contrast, does seek to offer reasons for why a believer might endorse religious Mooreanism. His reasons, which echo Plantinga's at points, do not consist in offering general criteria for determining when a belief has Moorean status. Instead they are as follows. (1) Evidence can be objectively misleading. (2) A perfectly loving and powerful God could design minds and environments such that theistic belief is epistemically

\footnotetext{
19 Something like this claim arguably explains why even Craig says that he would give up his Mooreanism if it were shown to face serious problems. Thus it doesn't seem questionbegging to hold Craig to a Socratic standard.
} 
safe from defeat. (3) A perfectly loving and powerful God would not allow a believer to be put into a condition where the rational thing for her to do would be to abandon her theistic belief. ${ }^{20}$

Beginning with the first claim, the idea that evidence can be misleading is both true and important. But the question is not whether evidence can be misleading but under what circumstances it is misleading, and what one's total evidence says. As for claim two, no doubt a perfect being could give religious belief Moorean force and vivacity. But this will not matter unless we grant Craig's third claim that God would never permit rationality defeaters for theism to be encountered.

In response to this latter theological claim, while I grant that a perfect personal God would likely care about theistic belief and seek to preserve it, one might wonder whether such a God would care nearly as much about properties such as justification, rationality, or warrant. ${ }^{21}$ Anyhow, there do seem to be some a priori considerations in favor of Craig's view. This is because we tend to think of knowledge and rationality as valuable-more valuable than mere true belief-and because a perfect God might be thought to care about valuable things. In addition, it may be that the knowledge of God in particular could promote a uniquely rich divine-human relationship, and perhaps this idea has scriptural support.

As with many intuitive ideas, though, the current one faces an empirical worry. To see why, consider the following two similarly a priori principles. NO EVIL: A perfectly loving and powerful God would not permit small children to suffer and die en masse. NO HIDDENNESS: A perfectly loving and powerful God would not permit notable amounts of non-resistant non-belief in God to occur. These principles can also seem very plausible and many think the second one, at least, has scriptural support. But virtually all theistic philosophers of religion, at least, have been forced to reject NO EVIL, since they observe that lots of infants do in fact suffer and die en masse. What's more, an increasing number of theistic philosophers of religion are starting to grant that there

\footnotetext{
20 The first reason appears in Craig 2014a. The latter two reasons can be found in Craig 2009

21 For all of Plantinga's discussion of Calvin and scripture, I can still imagine many intelligent theologians wondering why God would not be satisfied giving people psychological mechanisms to preserve religious belief, whether or not doing so was rational or warranted in most of the relevant and interesting senses that concern epistemologists.
} 
exists quite a bit of non-resistant non-belief as well, so many will further reject NO HIDDENNESS.

But then an internal problem arises for the idea that God would never (or let's say rarely) permit believers to confront rationality defeaters. Should we really think that Craig's NO DEFEAT view-that God would not tolerate irrational belief in God-has more weight than NO EVIL or NO HIDDENNESS? Are we really better at discerning God's attitudes toward epistemic defeat than evil and hiddenness? That seems far from obvious.

In fact, it is hard to maintain with a straight face that a perfectly loving God would care nearly as much about preserving rational or warranted theistic belief (when just theistic belief could be preserved anyhow) as God does about preserving the well-being of infants, or ensuring that lots of non-resistant non-belief does not occur. But then an internal, inductive challenge arises for Craig's view: those who reject NO EVIL, NO HIDDENNESS, or both should lower their confidence in Craig's claims about NO DEFEAT.

\subsubsection{Parity considerations}

There certainly could be other arguments against my charge that religious Mooreanism remains insufficiently motivated. For instance, someone might think that a parity argument for deeming religious belief properly basic could be easily reworked to support religious Mooreanism. Such a parity argument might go as follows. Clearly, many beliefs about the past are rational even in the absence of compelling arguments for their truth. There are, moreover, relevant similarities, and no decisive dissimilarities, between beliefs about the past and beliefs about God. For example, both are "natural" in the sense that they seem obviously true, are widespread, and are non-inferentially formed. Thus, it is plausible that many beliefs about God are rational in the absence of compelling arguments for their truth.

The updated Moorean version of this argument might then argue for another relevant similarity between beliefs about the past and beliefs about God. On this view, it is not simply that beliefs about the past are rational in the absence of compelling arguments for their truth. It is that arguments against the truth of such beliefs can in many cases be safely ignored or, more accurately, can be non-inferentially defeated. The updated Moorean argument might then be stated as follows: If beliefs 
about the past have more non-inferential weight than the challengers to them, and there are no relevant dissimilarities between beliefs about God and beliefs about the past, then beliefs about God plausibly have more non-inferential weight than the challengers to them. (This is similar, recall, to what Plantinga argues when he applies the idea of intrinsic defeater-defeaters both to traditional skepticism and to atheological challenges.)

This updated parity argument faces problems, however, and if anything reveals further challenges for religious Mooreanism. First, even assuming there are some Moorean facts, which is controversial, the parity argument is in an important respect anti-Moorean. After all, it is not as though Moore thought that any old belief could have Moorean status. He reserved this status for the most fundamental beliefs that almost no one questioned anyhow, such as our belief in the external world. But as our beliefs get (a) more controversial and (b) more subject to personal doubts, we may need to answer the skeptic's arguments in more sustained ways.

I do not mean to assert that Moorean beliefs are necessarily or always uncontroversial and difficult to doubt. The idea might just be that the more controversial and subject to personal doubts some belief $\mathrm{p}$ is, the better evidence we have that $\mathrm{p}$ lacks Moorean status. Perhaps there ought to be additional constraints on Moorean beliefs, such as epistemic safety or something similarly modal. Even without these additional constraints, though, religious Mooreanism already faces an epistemic hurdle since there are very relevant epistemic differences between beliefs about God and beliefs about the past.

For unlike specific religious beliefs, traditional Moorean beliefs are neither controversial, nor are they subject to serious doubts. Indeed, the near psychological impossibility of doubting the reality of motion or the past, for instance, stands in sharp contrast to religious beliefs, which are much more frequently doubted, even by religious epistemologists. ${ }^{22}$ Something like this asymmetry arguably explains why Moore didn't

\footnotetext{
22 Thanks to John Schellenberg for pointing out the involuntariness asymmetry, which is distinct from the doubt asymmetry. As for the doubt asymmetry, I recall Plantinga once claiming that occasionally he'll awake in the middle of the night asking if his religious outlook can be true, and that at other times this same outlook seems obvious. By contrast, few people have similar fluctuations when it comes to their belief in motion.
} 
apply Mooreanism to religious belief. It also helps to explain why religious skepticism represents a more live possibility than, say, motion skepticism.

Of course, one could argue that Moorean beliefs shouldn't be constrained at all in the aforementioned ways. But such an argument would have to be made, while addressing our earlier worry that one's epistemology permits far too many beliefs to have Moorean status. The permissiveness worry here isn't just the "Great Pumpkin Objection" to basic belief from religious epistemology either. For even if we grant that lots of controversial beliefs could be basic with respect to justification, rationality, or warrant, granting them Moorean status involves granting them a much stronger status. We need some constraints, and widespread agreement and difficulty to doubt seem like natural places to start. ${ }^{23}$

Perhaps if the priority of non-inferential evidence thesis could be established then parity arguments would become superfluous. This thesis, recall, claims that even highly controversial basic beliefs typically have far more weight than the best philosophical objections to those beliefs. Unfortunately, however, the target thesis has yet to be established. ${ }^{24}$ Some might think they have defended it by defending the idea that religious belief can be basic. But the basicality thesis, even if granted, might not support anything stronger than weak religious Mooreanism. Indeed, one largely neglected possibility is that rational religious belief is easy to obtain and easy to lose, at least for the philosophically curious.

\subsubsection{The ethics-religion analogy}

A better way to defend religious Mooreanism would be to draw a parallel with moral belief. If many moral beliefs can have Moorean status, then maybe many religious beliefs can too. This strategy does not require a

\footnotetext{
23 True, some theologians might think that theistic belief used to be uncontroversial and obvious before the Fall. But this claim, even if true, would not help now. Besides, as I have argued elsewhere, scientific accounts of religion suggest that the first humans lacked anything resembling theistic belief (Marsh 2013).

24 Plantinga's crime example would make for an interesting point of departure. But it is not nearly sufficient to build a general thesis about the priority of basic evidence over nonbasic evidence-not least since our beliefs about whether we have killed someone earlier today have much more vivacity than almost anyone's religious beliefs. In addition, to avoid conflating normative epistemology with empirical psychology, we should presumably not imply that someone's refusal to be challenged by arguments is evidence that she is being rational in all of the relevant senses that might interest epistemologists.
} 
general thesis about the priority of basic evidence over non-basic evidence. All that matters is that religion is like morality.

I think this is the religious Moorean's best bet. That is, I think the best way to establish religious Mooreanism is to make an analogy to moral Mooreanism. This is because moral belief has much more in common with religious belief than with our belief in the past. It is also because moral Mooreanism can seem tempting. After all, it can just seem that we know that it is objectively wrong to harm children for fun (not that it would be fun) with more confidence than any skeptical challenge that can-or at least will-arise. Similarly, it can just seem that we know that all humans are equal, even if this claim has been controversial.

As someone who also works in moral philosophy, I get the appeal of moral Mooreanism. I am thus not surprised to see someone like Louise Antony state: "Any argument for moral skepticism will be based upon premises which are less obvious than the existence of objective moral values themselves." ${ }^{25}$ Similarly, Elizabeth Anderson's claim that we know certain basic moral rules "with greater confidence than we know any conclusions drawn from elaborate factual or logical reasoning" (2007: 217), while arguably exaggerated, is not entirely shocking.

Unfortunately, though, this analogy to ethics also faces problems. One reason is that moral Mooreanism is itself a premature and controversial thesis. As has been noted elsewhere (McPherson 2009; Marsh 2014a: 23-4), moral Mooreanism is more often asserted than argued for and is less plausible than traditional forms of Mooreanism. Besides, there is a more fundamental problem facing the ethics-religion analogy, namely, that even if we decide to grant Moorean status to some moral beliefs, this would not automatically justify endorsing religious Mooreanism. This is because the moral beliefs most deserving of Moorean status (for example, it is wrong to harm children for fun) tend to be much more universal and less subject to doubt than the highly detailed, and typically Christian, beliefs that religious Mooreans often seek to assign Moorean status.

Turning to meta-ethical views, such as moral objectivism, even here many philosophers are hesitant to recommend a Moorean attitude. This is understandable. For even assuming, controversially, that ordinary people have consistently objectivist intuitions, when it comes to meta-ethics there

25 Or at least Craig attributes this claim to Antony (see Craig 2013). 
are intelligent nihilists, constructivists, and even a few error theorists, etc. who think that nothing is, strictly speaking, objectively wrong. Given the amount of expert disagreement about these matters, one might be cautious in insisting that any particular meta-ethical stance has Moorean status.

To clarify, the claim here is not that peer disagreement about moral matters should make us all agnostics about objectivism or skeptics about our basic moral convictions. The claim is much, much weaker: when there is sufficient expert disagreement about one's belief $p$, this should make one extremely hesitant to claim that the arguments against $\mathrm{p}$ can be deflected, whether or not one could answer those arguments. Although most epistemic principles are false, this one seems pretty good to me.

\subsection{A Demandingness Objection}

To be sure, difficult questions remain. For instance, even if moral and religious Mooreanism risk making belief preservation too easy, we do not wish to make it too hard either. And it's not always clear how to strike the right balance here (Marsh 2014b). This is an instance of a wider problem about how hard rationality and knowledge should be, not least in cases where belief revision would involve seriously altering one's basic identities and way of life. I do not think that anyone has resolved this problem. Even so, several considerations make the problem less than fully pressing in the contexts of morality and religion. Let me conclude by stating them.

First, it is not clear that religious and moral Mooreanism are even required to preserve widespread rationality. Most people cannot even say what the problem of evil is or what the main challenges to moral realism are, for instance. Second, those who do come across serious versions of these challenges might Google responses to them, if they are interested enough to do so, exploring the debates in more detail.

Third, even if not everyone is up to the task of answering the relevant challenges, shouldn't preserving rationality while encountering complex arguments about controversial matters be a bit hard? For instance, when it comes to debates about same-sex marriage and abortion, beliefs that also shape people's identities and ways of life, we do not typically promote Moorean attitudes for anyone. In these contexts we expect people to be responsive to evidence and arguments. 
Another point is worth mentioning in addition. When it comes to controversial moral beliefs, such as basic equality, the appeal of Mooreanism might be more practical and political than epistemic in nature. But we can treat ideas, like equality, as fundamental and authoritative in a social and political sense without taking a Moorean stance on their meta-epistemological standing. These suggestions, combined with the thought that beliefs can be epistemically secure without having Moorean status anyhow, means that the stakes in failing to endorse moral and religious Mooreanism are not as high as some might suppose.

True, it's possible that Mooreanism in one or both of these domains will be shown to be a good idea. And maybe carefully following a Socratic path will eventually lead us straight to Moorean methodology in the philosophy of religion. But my point is that this latter path has yet to be carved out and, further, seems implausible at first glance. ${ }^{26}$

\section{References}

Anderson, E. (2007), "If God Is Dead, Is Everything Permitted?" in L. Antony (ed.), Philosophers without Gods: Meditations on Atheism and the Secular Life (New York: Oxford University Press), 215-30.

Bergmann, M. (2014), "Epistemic Intuitions and Defeaters for Noninferential Religious Belief" [podcast], sixth and final talk given at the Defeat and Religious Epistemology for the New Insights and Directions in Religious Epistemology Workshop, 17 March 2014, Oxford University <https://pod casts.ox.ac.uk/epistemic-intuitions-and-defeaters-noninferential-religious-belief> accessed July 3, 2017.

Buchak, L. (2012), "Can It Be Rational to Have Faith?" in J. Chandler and V. Harrison (eds.), Probability in the Philosophy of Religion (Oxford: Oxford University Press), 225-47.

Craig, W. L. (2008), Reasonable Faith: Christian Truth and Apologetics, 3rd edn (Wheaton, IL: Crossway Books).

Craig, W. L. (2009), "The Witness of the Spirit as an Intrinsic Defeater-Defeater," in "Q\&A with William Lane Craig \#136," Reasonable Faith with William Lane

\footnotetext{
${ }^{26}$ Thanks to William Abraham, Fred Aquino, Kenny Boyce, Gary Colwell, Arthur Cunningham, Jason Decker, Keith DeRose, Travis Dumsday, Jonathan Fuqua, John Greco, Jeanine Grenberg, Dan Groll, Stephen Grimm, Liz Jackson, Mike Rea, Danny Muñoz-Hutchinson, Corliss Swain, and Charles Taliaferro for helpful discussion. Thanks especially to Paul Draper, Jon Marsh, and John Schellenberg for detailed feedback on an earlier draft and also to my audiences in Atlanta and Edmonton for their comments.
} 
Craig [website], November 23, $2009<$ http://www.reasonablefaith.org/thewitness-of-the-spirit-as-an-intrinsic-defeater-defeater $>$ accessed July 3, 2017. Craig, W. L. (2013), “Those Who Deny Objective Moral Values" [podcast], Reasonable Faith with William Lane Craig [website], April 22, $2013<\mathrm{http} / / /$ www.reasonablefaith.org/Those-Who-Deny-Objective-Moral-Values $>$ accessed July $3,2017$.

Craig, W. L. (2014a), "Indefeasibility and Openness to Evidence," in "Q\&A with William Lane Craig \#381," Reasonable Faith with William Lane Craig [website], August 3, 2014 <http://www.reasonablefaith.org/indefeasibilityand-openness-to-evidence> accessed July 3, 2017.

Craig, W. L. (2014b), "The End of Philosophy of Religion" [podcast], Reasonable Faith with William Lane Craig [website], October 26, 2014 <http://www. reasonablefaith.org/the-end-of-philosophy-of-religion> accessed July 3, 2017.

Kelly, T. (2005), "Moorean Facts and Belief Revision, or Can the Skeptic Win?" Philosophical Perspectives 19, 179-209.

Kelly, T. (2011), "Following the Argument Where It Leads," Philosophical Studies 154, 105-24.

Leon, F. (2010), "Intrinsic Defeaters and the Plantinga-Quinn Debate," ExApologist: A Philosophy of Religion Blog", February 18, $2010<\mathrm{http} / / / \mathrm{ex}$ apologist.blogspot.com/2010/02/intrinsic-defeaters-and-plantinga-quinn.html> accessed July 3, 2017.

Marsh, J. (2013), "Darwin and the Problem of Natural Nonbelief," The Monist $96 / 3,349-76$.

Marsh, J. (2014a), "Quality of Life Assessments, Cognitive Reliability, and Procreative Responsibility," Philosophy and Phenomenological Research 89/2, 436-66.

Marsh, J. (2014b), “Conscientious Objection and Reason Giving," Bioethics 28, 313-19.

McGrew, L. (2010), “CPBD 071: Lydia McGrew-The Probability of Christianity" [podcast interview by Luke Muehlhauser], Common Sense Atheism [website], October 6, $2010<$ http://commonsenseatheism.com/?p=10555> accessed July 3, 2017.

McPherson, T. (2009), "Moorean Arguments and Moral Revisionism," Journal of Ethics \& Social Philosophy 3/2.

Plantinga, A. (1986), "Foundations of Theism: A Reply," Faith and Philosophy 3/3, 298-313.

Plantinga, A. (2000), Warranted Christian Belief (Oxford: Oxford University Press). Plantinga, A. (2001), "Rationality and Public Evidence," Religious Studies 32, 215-22.

Plantinga, A. (2011), Where the Conflict Really Lies: Science, Religion, and Naturalism (New York: Oxford University Press). 
Price, H. (2007), "Starving the Theological Cuckoo: A Review of John Leslie, Infinite Minds: A Philosophical Cosmology," Spontaneous Generations: A Journal for the History and Philosophy of Science 1, 136-45.

Rowe, W. L. (1979), "The Problem of Evil and Some Varieties of Atheism," American Philosophical Quarterly 16/4, 335-41.

Schellenberg, J. L. (2007), The Wisdom to Doubt: A Justification of Religious Skepticism (Ithaca, NY: Cornell University Press). 